\title{
CHRONIC DIARRHEA IN SOLDIERS; FACTS
}

\section{Muhammad Hafeez, Farrukh Saeed, Zafar Qureshi, Saad Rao, Fuad Ahmad Siddiqi*}

Pak Emirates Military Hospital/National University of Medical Sciences (NUMS) Rawalpindi Pakistan, *Combined Military Hospital/ National University of Medical Sciences (NUMS) Rawalpindi Pakistan

\section{ABSTRACT}

Objective: To find out the underlying causes of chronic diarrhea in soldiers and how it differs from general population. Study Design: Prospective comparative study.

Place and Duration of Study: Combined Military Hospital (CMH) Multan and Pak Emeritus Military Hospital (PEMH) Rawalpindi, from Dec 2017 to Jan 2020.

Methodology: All soldiers in active service, having diarrhea more than 4 weeks in study and non-soldiers of the same age were included in the control group. There were inquired in details about the diarrhea symptoms and investigations carried out accordingly to find out the underlying cause. The two groups were compared to find out any differences. The data were analyzed by SPSS version 22 .

Results: Seventy one in study and 50 patients in control had their mean ages of $34.61 \pm 8.35$ and $32.42 \pm 10.28$ years. Mean duration of symptoms were 18 and 15 months in study and control groups respectively. Irritable Bowel Syndrome (IBS) was more common in both groups i.e. $14(20 \%)$ and $20(40 \%)$ in study and control groups respectively but frequency was more in second one. Seropositive celiac disease 13 (18.5\%), seronegative villous atrophy 10 (14\%) in study and Inflammatory Bowel Disease IBD 6 (12\%) in control group were second most common conditions.

Conclusions: Irritable bowel syndrome is common in this age group. Celiac and seronegative villous atrophy is second common conditions in the study group.

Keywords: Chronic diarrhea in soldiers, Chronic diarrhea, Celiac disease, Irritable bowel syndrome (diarrhea).

This is an Open Access article distributed under the terms of the Creative Commons Attribution License (http://creativecommons.org/licenses/by/4.0), which permits unrestricted use, distribution, and reproduction in any medium, provided the original work is properly cited.

\section{INTRODUCTION}

Chronic diarrhea is defined by $\geq 3$ stools/ day, or stools weight $>200 \mathrm{gm}$ and duration of $\geq 4$ weeks. It effects $5 \%$ of the population at a given time ${ }^{1,2}$. Chronic diarrhea is broadly divided in to different groups according to its pathophysiology, a number of diseases fall into each group ${ }^{3}$. Motility disorders that can lead to diarrhea are IBS according to Rome IV criteria ${ }^{4}$, hyperthyroidism and diabetic autonomic neuropathy. Inflammatory bowel disease includes two major diseases i.e. ulcerative colitis and crohn's disease. Ulcerative colitis is the inflammatory condition confined to colonic mucosa ${ }^{5}$. Crohn's disease is a transmural inflammation with skip lesion can affect any part of the gut from mouth to anus. Infectious diseases include pseudomembranous colitis, Tuberculosis etc. Secretory diarrhea may occur in laxative abuse, post cholecystectomy. Microscopic colitis presents with watery diarrhea usually affects the middle aged patients but can affect children as well. It is diagnosed on histopathology of distal colon. There are two further subtypes i.e. lymphocytic and collagenous colitis ${ }^{6}$. Malabsorption is impairment in absorption of nutrients caused by any

Correspondence: Dr Muhammad Hafeez, Classified Medical Specialist, PEMH Rawalpindi Pakistan

Received: 26 May 2020; revised received: 28 Sep 2020; accepted: 01 Oct 2020 disruption in the process of normal absorption at luminal, brush border processing and absorption into the intestinal mucosa or transport into the circulation. Diseases involving the mucosal brush border are celiac disease, giardiasis, tropical sprue7. A number of studies have done on the spectrum of the diseases related to chronic diarrhea in the general population ${ }^{8}$, and acute diarrhea in the army personals ${ }^{9}$, but yet to see any study that has focused on this important topic. As chronic diarrhea can lead severe morbidity and badly affect the working capability of the soldier, this study was designed to find the different etiological factors and how they differ from the general population of the same age group.

\section{METHODOLOGY}

This was prospective comparative study. It was carried out at CMH Multan and PEMH from Dec 2017 to Jan 2020. This was improved by the ethics committee of the hospitals, certificate no A/28/EC/116/20. Consecutive convenient sampling was done. All patients presented with 4 weeks history of diarrhea during this duration were included in the study. Patients unwilling to participate, further investigations or lost to follow up were excluded from the study. The patients' informed consent was taken from both the groups. They were asked about duration of the symptoms, 
history of traveling, use of antibiotics or intestinal malignancy in the family. They were inquired in details about symptoms like consistency, colour of stool, any mucous or blood in it. They were further asked about nocturnal symptoms, weight loss or heat intolerance etc. Investigations were done according to possible diagnosis based on the history like blood counts, stool examination, renal, liver functions, thyroid profile, anti-tissue transglutaminase (anti-TTG anti-bodies) IgG A and IgG type. Upper GI endoscopy with duodenal biopsies, colonoscopy with mucosal biopsies and contrast enhanced CT scan of abdomen where ever indicated were also done.

The data were analyzed by SPSS-22. The descriptive statistical methods were used for mean \pm standard deviation and percentage. The chi-square test was used in the comparison of qualitative data. $p$-value $\leq 0.5$ was considered statistically significant.

\section{RESULTS}

Out of 121 there were 71 patients in study and 50 patients in the control group. Mean age of the two groups were $34.62 \pm 8.35$ and $32.42 \pm 10.28$ years without statistically significant difference, $p$ (0.693). Average duration of symptoms in study and control groups was 18 and 15 months respectively. History of smoking, travel, bowel malignancy in family, bleed per rectum, nocturnal symptoms and weight loss were more common in study group (table-I).

IBS was common in both groups but with more frequency in control group. Celiac disease along with its associated problems like microscopic colitis, intestinal malignancy, hypothyroidism and hyperthyroidism, bowel malignancy, microscopic colitis and megaloblastic anemia were second more common conditions in study group as compared to control group in which IBD dominates. However there was no statistically significant difference in the two groups $(p=0.923)$.

\section{DISCUSSION}

Chronic diarrhea has a spectrum of diseases with different age prevalence in each disease. Diarrhea is less common in patients with age more than $60^{10}$. The mean age in our study group was 34 years that was almost the same as control group i.e. 32 years. IBS is considered to be common in this age group because of etiological association with the chronic diarrhea like stress $^{11}$, and post infections ${ }^{12,13}$. In our study IBS was common in both groups i.e. $20 \%$ and $40 \%$ study and control groups respectively, though frequency was more common in secondone. Pooled global prevalence
Table-I: Demographic/clinical differential features of the study and control group.

\begin{tabular}{|c|c|c|}
\hline & $\begin{array}{c}\text { Study group } \\
n=71\end{array}$ & $\begin{array}{c}\text { Control group } \\
n=50\end{array}$ \\
\hline Mean age \pm SD & $34.61 \pm 8.35$ yrs & $32.42 \pm 10.28$ \\
\hline \multicolumn{3}{|l|}{ Symptoms } \\
\hline Mean duration & 18 months & 15 months \\
\hline \multicolumn{3}{|l|}{ Smoker } \\
\hline Yes & $19(27 \%)$ & $05(10 \%)$ \\
\hline No & $52(73 \%)$ & $45(90 \%)$ \\
\hline \multicolumn{3}{|l|}{ Travel history } \\
\hline Yes & $23(32 \%)$ & $02(4 \%)$ \\
\hline No & $48(68 \%)$ & $48(96 \%)$ \\
\hline \multicolumn{3}{|c|}{ Family history of bowel malignancy } \\
\hline Yes & $3(4 \%)$ & - \\
\hline No & $68(96 \%)$ & $50(100 \%)$ \\
\hline \multicolumn{3}{|l|}{ Blood in stool } \\
\hline Yes & $16(23 \%)$ & $7(14 \%)$ \\
\hline No & $55(77 \%)$ & $43(86 \%)$ \\
\hline \multicolumn{3}{|c|}{ Nocturnal diarrhea } \\
\hline Yes & $37(52 \%)$ & $18(36 \%)$ \\
\hline No & $34(48 \%)$ & $38(64 \%)$ \\
\hline \multicolumn{3}{|l|}{ Weight loss } \\
\hline Yes & $35(49 \%)$ & $9(18 \%)$ \\
\hline No & $36(51 \%)$ & $41(82 \%)$ \\
\hline \multicolumn{3}{|l|}{ Rash } \\
\hline Yes & $15(21 \%)$ & $4(8 \%)$ \\
\hline No & $55(79 \%)$ & $44(92 \%)$ \\
\hline
\end{tabular}

Table-II: Frequency of different diseases in both groups with their percentage.

\begin{tabular}{l|c|c}
\hline Diagnosis & $\begin{array}{c}\text { Study } \\
\text { group, } \\
\mathbf{n}(\mathbf{\%})=\mathbf{7 1}\end{array}$ & $\begin{array}{c}\text { Control } \\
\text { group, } \\
\mathbf{n}(\mathbf{\%})=50\end{array}$ \\
\hline Abdominal Tuberculosis & $2(2.8)$ & - \\
\hline Antibiotic associated diarrhea & $2(2.8)$ & $1(1.4)$ \\
\hline Celiac (sero-pos+ villous atrophy) & $10(14.1)$ & $6(8.5)$ \\
\hline Celiac and microscopic colitis & $1(1.4)$ & - \\
\hline Celiac with intestinal malignancy & $1(1.4)$ & - \\
\hline Celiac+ Hypothyroidism & $1(1.4)$ & - \\
\hline Diabetic autonomic neuropathy & $1(1.4)$ & - \\
\hline H Pylori associated Diarrhea & $1(1.4)$ & $2(4)$ \\
\hline Hyperthyroidism & $2(2.8)$ & $3(6)$ \\
\hline $\begin{array}{l}\text { Irritable bowel syndrome } \\
\text { (diarrhea) }\end{array}$ & $14(19.4)$ & $20(40)$ \\
\hline $\begin{array}{l}\text { Megaloblastic associated } \\
\text { diarrhea }\end{array}$ & $1(1.4)$ & - \\
\hline Microscopic colitis & $8(11.3)$ & $7(14)$ \\
\hline Post colectomy diarrhea & $2(2.8)$ & $1(2)$ \\
\hline Seronegative villous atrophy & $7(9.9)$ & $2(4)$ \\
\hline $\begin{array}{l}\text { Seronegative villous atrophy and } \\
\text { Megaloblastic anemia }\end{array}$ & $3(4.2)$ & - \\
\hline Travelers diarrhea & $6(8.5)$ & - \\
\hline Ulcerative colitis & $9(12.7)$ & $6(12)$ \\
\hline Giardia/tinea saginata & $71(100)$ & $2(4)$ \\
\hline Total & &
\end{tabular}


Table-III: Chi-square tests.

\begin{tabular}{l|c|c|c}
\hline & Value & DF & $\begin{array}{c}\text { Asymp. Sig. } \\
\text { (2-sided) }\end{array}$ \\
\hline Pearson Chi-Square & $179.706^{*}$ & 208 & 0.923 \\
\hline Likelihood Ratio & 103.896 & 208 & 1.000 \\
\hline N of Valid Cases & 71 & - & - \\
\hline *238 cells (100.0\%) have expected count $>5$. The minimum \\
expected count is 0.01.
\end{tabular}

of celiac is $0.7 \%$ and in Asia $0.6 \%$. It is more common in children as compared to adults and in females in contrast to males ${ }^{14}$. Seropositive and sero-negative intestinal villous atrophy along with other autoimmune disease like hypothyroidism, GI malignancy and microscopic colitis was more common in study group. This is a matter of serious concern that every soldier presenting with diarrhea $>4$ weeks should be thoroughly investigated and celiac disease must be ruled out to avoid disability, complications and dietary modifications can be advised accordingly. In case of seronegative small intestinal villous atrophy conditions like infections, inflammations, immune mediated disorders and drugs should be considered ${ }^{15}$. HLA DQ2 and DQ8 used to confirm the celiac in sero-negative villous atrophy, negative results rule out celiac but it is not positive in all cases of villous atrophy that necessitate to rule out other causes ${ }^{16}$. Apart from war injuries travelers' diarrhea always remained a military problem because of the frequent soldiers' traveling ${ }^{17}$. Thirty two percent of the subjects in the study group had frequent history of traveling and $8.5 \%$ out of them had chronic diarrhea and no one in the control group. Out of inflammatory Bowel Disease, crude incidence of ulcerative colitis in India was $6.02 \%$ and prevalence exceed beyond $0.3 \%$ in North America and Europe ${ }^{18}$. Prevalence of ulcerative colitis in both study and control groups was 12.7 and $12 \%$ respectively, that is quite high. There was no case of Crohn's disease in both groups. Other causes of diarrhea with less frequency in both groups were secondary to H.Pylori, antibiotic use, post colectomy, diabetes with autonomic neuropathy and secondary to giardiasis were present without much difference.

\section{LIMITATION OF STUDY}

Limited number of ladies was there in the study group so the statistics may not be true representation in this gender group

\section{ACKNOWLEDGEMENT}

We want to pay special thanks to our staff, training doctors for helping in gathering the data and completing the study.

\section{CONCLUSION}

IBS was more common in both groups though frequency was more in control group. Seropositive CD, seronegative villous atrophy in study and IBD in control group were second commonest conditions in this study. However there was no statistically significant difference in the two groups $(p=0.923)$. Etiological differences is a food for thought to do more studies on this topic.

\section{CONFLICT OF INTEREST}

This study has no conflict of interest to be declared by any author.

\section{REFERENCES}

1. Schiller LR, Pardi DS, Sellin JH. Chronic diarrhea: diagnosis and management. Clin Gastroenterol Hepatol 2017; 15(2): 182-93.

2. Fine KD, Schiller LR. AGA technical review on the evaluation and management of chronic diarrhea. Gastroenterol 1999; 116(1): 1464-68.

3. Schmulson MJ, Drossman DA. What is new in Rome IV. J Neurogastroenterol Motil 2017; 23(2): 151-63.

4. Silverberg MS, Satsangi J, Ahmad T, Bernstein CN, Brant SR, Caprilli $\mathrm{R}$, et al. Toward an integrated clinical, molecular and serological classification of inflammatory bowel disease: report of a working party of the 2005 montreal world congress of gastroenterology. Can J Gastroenterol 2005; 19(Suppl-1): 1-5.

5. Pardi DS, Kelly CP. Microscopic colitis. Gastroenterol 2011; 140(2): 1155-65.

6. Clark R, Johnson R. Malabsorption Syndromes. Nurs Clin North Am 2018; 53(3): 361-74.

7. Daoud D, Bouin M, Bellemare L, Nemer M. Prevalence of chronic diarrhea amongst patients followed in gastroenterology. J Can Assoc Gasteroenterol 2018; 1(Supply-2): 264.

8. Mullaney SB, Rao S, Salman. Magnitude, distribution, risk factors and care-seeking behaviour of acute, self-reported gastrointestinal illness among US Army Soldiers. Pub Onl Cam Uni Press 2015; 13(147): 1-18.

9. Sandler RS, Stewart WF, Liberman JN, Ricci JA, Zorich NL. Abdominal pain, bloating, and diarrhea in the United States: prevalence and impact. Dig Dis Sci 2000; 45(6): 1166-71.

10. Talley NJ, Zinsmeister AR, Van Dyke C, Melton LJ. Epidemiology of colonic symptoms and the irritable bowel syndrome. Gastroenterol 1991; 101(4): 927-34.

11. Klem F, Wadhwa A, Larry J. Prokop Wendy Sundt, Gianrico Farrugia, Michael Camilleri et al. Prevalence, risk factors, and outcomes of irritable bowel syndrome after infectious enteritis: a systematic review and meta-analysis. Gastroenterol 2017; 5(1): 1042-54.

12. Distrutti E, Monaldi L, Ricci P, Fiorucci S. Gut microbiota role in irritable bowel syndrome: New therapeutic strategies. World J Gastroenterol 2016; 22(7): 2219-41.

13. Prashant S, Arora A, Tor A, Leffler DA, Catassi C, Green PH, et al. Global prevalence ofceliac disease: systematic review. Clin Gastroenterol Hepatol 2018; 16(6): 823-36.

14. Aziz I, Peerally MF, Barnes J, Kandasamy V, Whiteley JC, Partridge $\mathrm{D}$, et al. The clinical and phenotypical assessment of seronegative villous atrophy; a prospective UK centre experience evaluating 200 adult cases over a 15-year period (2000-2015). Gut 2017; 66(9): 1563-72. 
15. Ayesh BM, Zaqout EK, Yassin MM. HLA-DQ2 and-DQ8 haplotypes frequency and diagnostic utility in celiac disease patients of Gaza strip, Palestine. Auto Immun Highlights 2017; 8(1): 11-9.

16. Connor P, Farthing MJ.Travelers'diarrhea: a military problem?. J R Army Med Corps 1999; 145(2): 95-01.

17. Sood A, Midha V, Sood N, Bhatia AS, Avasthi G. Incidence and prevalence of ulcerative colitis in Punjab, North Ind Gut 2003; 52(11): 1587-90.

18. The global, regional, and national burden of inflammatory bowel disease in 195 countries and territories, 1990-2017: a systematic analysis for the Global Burden of Disease Study 2017. Lancet Gastroenterol Hepatol 2020; 5(1): 17-30. 